\title{
Enhanced Fenton-like degradation of pharmaceuticals over framework copper species in copper-doped mesoporous silica microspheres
}

\author{
Lai Lyu, Lili Zhang, Chun $\mathrm{Hu}^{*}$ \\ Key Laboratory of Drinking Water Science and Technology, Research Center for Eco-Environmental Sciences, Chinese Academy of Sciences, Beijing 100085, China
}

\section{H I G H L I G H T S}

- $0.91 \mathrm{wt} \%$ Cu could exist in the framework of Cu-MSMs by the binding of $\mathrm{Si}-\mathrm{O}-\mathrm{Cu}$.

- PHT, IBU and DP disappeared within 75,120 and 90 min, respectively, in the $\mathrm{M}_{2} / \mathrm{H}_{2} \mathrm{O}_{2}$ system at neutral $\mathrm{pH}$.

- The leaching of $\mathrm{Cu}$ was much lower than the EU directives in the $\mathrm{M}_{2} / \mathrm{H}_{2} \mathrm{O}_{2}$ system.

- The phenolic products complexed with the framework $\mathrm{Cu}(\mathrm{II})$, forming $\equiv \mathrm{Cu}$-ligands.

- $\equiv$ Cu-ligands interacted with $\mathrm{H}_{2} \mathrm{O}_{2}$, accelerating the $\mathrm{Cu}(\mathrm{II}) / \mathrm{Cu}(\mathrm{I})$ cycles.

\section{A R T I C L E I N F O}

\section{Article history:}

Received 6 February 2015

Received in revised form 27 March 2015

Accepted 30 March 2015

Available online 4 April 2015

\section{Keywords:}

Fenton-like

Framework copper

Mesoporous silica

Pharmaceuticals

Cu-ligands

\section{G R A P H I C A L A B S T R A C T}

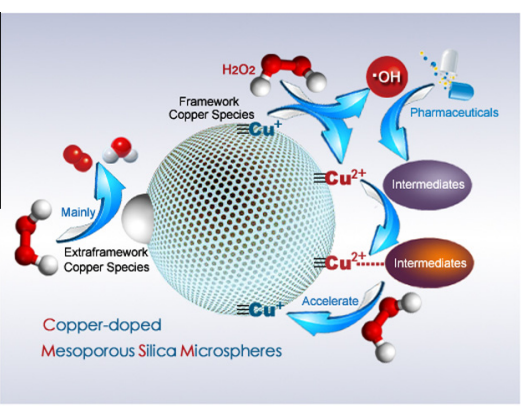

\begin{abstract}
A B S T R A C T
Copper-doped mesoporous silica microspheres (Cu-MSMs) with the coexistence of $\mathrm{Cu}(\mathrm{I})$ and $\mathrm{Cu}(\mathrm{II})$ were prepared using a hydrothermal process and characterized by several methods. The characterization studies suggested that $0.91 \mathrm{wt} \%$ of the copper species could exist in the framework of the mesoporous silica microspheres by chemical binding of $\mathrm{Si}-\mathrm{O}-\mathrm{Cu}$; excess copper species were located in the extraframework sites, leading to more oxygen vacancies on the surface of the catalysts. The framework $\mathrm{Cu}$ of $\mathrm{Cu}-\mathrm{MSM}$ was found to be highly effective and stable for the degradation of pharmaceutical pollutants, as demonstrated with phenytoin, ibuprofen and diphenhydramine in the presence of $\mathrm{H}_{2} \mathrm{O}_{2}$ at neutral $\mathrm{pH}$ values. The conversion of the three pharmaceuticals could reach $100 \%$ within 75,120 and 90 min, respectively; the leaching of Cu was much lower than the EU directives and USA regulations. By the studies of electron spin resonance, gas chromatography-mass spectrometry, Fourier-transform infrared spectra, in situ Raman spectra and Xray photoelectron spectroscopy, an interaction process among the framework $\mathrm{Cu}$ of $\mathrm{Cu}-\mathrm{MSMs}$, pharmaceuticals and $\mathrm{H}_{2} \mathrm{O}_{2}$ was proposed: During the Fenton-like reaction, the framework $\equiv \mathrm{Cu}(\mathrm{I})$ in $\mathrm{Cu}-\mathrm{MSM}$ primarily converted $\mathrm{H}_{2} \mathrm{O}_{2}$ into $\cdot \mathrm{OH}$, and $\equiv \mathrm{Cu}(\mathrm{I})$ was oxidized to $\equiv \mathrm{Cu}(\mathrm{II})$ by $\mathrm{H}_{2} \mathrm{O}_{2}$. The pharmaceuticals were attacked by $\mathrm{OH}$ to form phenolic intermediates, adsorbing on the surface of $\mathrm{Cu}-\mathrm{MSM}$, complexing with the framework $\equiv \mathrm{Cu}(\mathrm{II})$, forming $\equiv \mathrm{Cu}$-ligands. $\equiv \mathrm{Cu}$-ligands interacted with $\mathrm{H}_{2} \mathrm{O}_{2}$ and enhanced the reduction rate of $\equiv \mathrm{Cu}(\mathrm{II})$, resulting in the more $\equiv \mathrm{Cu}(\mathrm{I})$ production; consequently, accelerated the $\mathrm{Cu}(\mathrm{II}) / \mathrm{Cu}(\mathrm{I})$ cycles on the catalyst surface, leading to more $\cdot \mathrm{OH}$ generation for the pharmaceuticals oxidation.
\end{abstract}

(c) 2015 Elsevier B.V. All rights reserved.

\footnotetext{
* Corresponding author. Tel.: +86 10 62849628; fax: +86 1062923541

E-mail address: huchun@rcees.ac.cn (C. Hu).
}

\section{Introduction}

Pollution from pharmaceutical compounds (PhACs) in surface and ground waters is an environmental concern in many countries $[1,2]$. Although the detected concentration levels of PhACs in 
aqueous environment are low and often range from ng/L to $\mu \mathrm{g} / \mathrm{L}$ levels, the potential dangers to human and ecological health exist due to long-term exposure [3]. PhACs show a wide range of persistence in aquatic environments, and most of them are highly persistent, which could not be completely eliminated by the conventional water treatment [4].

Among the advanced oxidation processes (AOPs), the Fenton process is a powerful method to produce the high oxidation potential of the hydroxyl radical $(\cdot \mathrm{OH})$ for the degradation of the recalcitrant organic pollutants $[5,6]$. However, the application of the classic Fenton process (dissolved $\mathrm{Fe}^{2+}$ and $\mathrm{H}_{2} \mathrm{O}_{2}$ ) is limited by the narrow working $\mathrm{pH}$ range of $2-3$ as well as the separation and recovery of the iron species [7]. In order to address these problems, heterogeneous Fenton catalysts such as montmorillonites [8], zeolites [9], and metal oxides [10] were developed for use instead of the homogeneous Fenton process. These developed heterogeneous catalysts avoid the need for large amounts of reducing metal ions, which has been an active research area in this field. However, most of them showed good catalytic activity from $\mathrm{pH} 3$ to 5 , and a few of them showed significant catalytic efficiency at neutral $\mathrm{pH}$ values in water. It has been accepted that $\mathrm{H}_{2} \mathrm{O}_{2}$ is decomposed into $\mathrm{OH}$ by the cycle of reduction state $\left(\mathrm{M}^{n+}\right)$ and oxidation state $\left(\mathrm{M}^{(n+m)+}\right)$ of the metal with the reduction of $\mathrm{M}^{(n+m)+}$ to $\mathrm{M}^{n+}$ by oxidizing $\mathrm{H}_{2} \mathrm{O}_{2}$ being the rate-limiting step in the overall reaction [11,12]. For example, $\mathrm{Fe}(\mathrm{III}) / \mathrm{Fe}(\mathrm{II})$ cycling is heavily retarded by the slow step of $\mathrm{H}_{2} \mathrm{O}_{2}$ reducing $\mathrm{Fe}(\mathrm{III})$ due to the low rate constants (0.001$0.02 \mathrm{M}^{-1} \mathrm{~s}^{-1}$ ) in neutral condition [12], which often need the aid of ultrasound and UV/visible light irradiation, increasing the energy requirements and the cost for water treatment.

Recently, Cu-based catalysts have attracted considerable attention because the redox properties of copper are similar to iron, and the Cu-based Fenton-like system could work over a broader $\mathrm{pH}$ range than the Fe-based redox system $[13,14]$. Importantly, the reduction of $\mathrm{Cu}$ (II) by $\mathrm{H}_{2} \mathrm{O}_{2}\left(4.6 \times 10^{2} \mathrm{M}^{-1} \mathrm{~s}^{-1}\right)$ occurs more easily than that of $\mathrm{Fe}(\mathrm{III})$, and the $\mathrm{Cu}(\mathrm{I})-\mathrm{H}_{2} \mathrm{O}_{2}$ system, which possesses a higher reaction rate $\left(1 \times 10^{4} \mathrm{M}^{-1} \mathrm{~s}^{-1}\right)$ than the $\mathrm{Fe}(\mathrm{II})-\mathrm{H}_{2} \mathrm{O}_{2}$ system (76 $\mathrm{M}^{-1} \mathrm{~s}^{-1}$ ), can efficiently produce $\mathrm{OH}[13,15,16]$. Due to the mobilization of $\mathrm{Cu}(\mathrm{II}) / \mathrm{Cu}(\mathrm{I})$ in water, copper has been suggested to be supported on a porous solid substrate. $\mathrm{Cu} / 13 \mathrm{X}$ [17], $\mathrm{Cu} /$ SBA-15 [18], and Cu-containing MFI [19] zeolites have been reported as catalysts for wet peroxide oxidation of different organic pollutants. But up to now, the correlation between the copper state in the structure of the catalysts and their catalytic activity was still unclear. Moreover, $\mathrm{Cu}(\mathrm{II})$ is easily complexed with organic substances [20], which may be used to enhance the catalytic activity [21]. However, the complexing of organic ligands with metal could accelerate the release of metal ions in aqueous solution from the solid catalyst, destructing the structure of the catalyst [22]. It was found that $0.5-10 \mathrm{mg} \mathrm{L}^{-1}$ of $\mathrm{Cu}$ were released into the solutions in various reported $\mathrm{Cu}$-based heterogeneous Fenton-like systems $[23,24]$, which was much higher than the standard $1.3 \mathrm{mg} \mathrm{L}^{-1}$ of drinking water (National Primary Drinking Water Regulations, the United States). The $\mathrm{Cu}$ release might be inhibited by the chemical bonding of $\mathrm{Cu}$ in the structure of the catalyst.

In the present study, copper-doped mesoporous silica microspheres (Cu-MSMs) were synthesized by a hydrothermal method. The localized copper species in the structure of Cu-MSMs were characterized, and their catalytic performance was investigated by Fenton-like process. Phenytoin (PHT) is a representative antiepileptic drug. Chronic exposure to it can result in immune suppression and dermatosis even the concentration is low [25]. Ibuprofen (IBU), an anti-inflammatory drug, may alter the postembryonic development of anuran species in freshwater environs [26]. Diphenhydramine (DP) is the active ingredient of Benadryl, a first generation antihistamine drug that combines sedative, antiemetic, antitussive and hypnotic properties, and has shown high toxicity with mutagenic and carcinogenic effects [27]. The three PhACs occurred extensively in the aquatic environment due to their high usage and their presence in wastewater [28]. Therefore, PHT, IBU and DP were selected to evaluate the activity and properties of the catalyst. The results indicated that the framework copper species in Cu-MSMs exhibited high efficiency and stability for the degradation of the PhACs in the presence of $\mathrm{H}_{2} \mathrm{O}_{2}$ at neutral $\mathrm{pH}$ values. A preliminary effort to identify the interaction process among the framework copper species of $\mathrm{Cu}-\mathrm{MSMs}$, PhACs and $\mathrm{H}_{2} \mathrm{O}_{2}$ has been undertaken.

\section{Materials and methods}

\subsection{Materials and reagents}

Two of the PhACs-DP and PHT were purchased from Acros (Geel, Belgium), and IBU was obtained from TCI Japan (Tokyo, Japan). Their purities were higher than $99 \%$. Their molecular structures are shown in Fig. S1. Tetraethyl orthosilicate (TEOS), cetyltrimethyl ammonium bromide (CTAB), copper nitrate trihydrate $\left(\mathrm{Cu}\left(\mathrm{NO}_{3}\right)_{2} \cdot 3 \mathrm{H}_{2} \mathrm{O}\right)$, hydrogen peroxide $\left(\mathrm{H}_{2} \mathrm{O}_{2}, 30 \%\right.$, w/w), absolute ethanol and ammonia solution were purchased from Sinopharm Chemical Reagent Co. 5-Tert-butoxycarbonyl-5-methyl-1-pyrroline-N-oxide (BMPO) was provided by Dojindo Molecular Technologies. N,N-diethyl-p-phenylenediamine sulphate (DPD) and horseradish peroxidase (POD) were provided by Sigma Ltd. N,O-bis(Trimethylsilyl)trifluoroacetamide (BSTFA) was obtained from TCI Japan (Tokyo, Japan). All of the chemicals were at least of analytical grade. Deionized water was used throughout this study.

\subsection{Catalyst preparation}

$\mathrm{Cu}-\mathrm{MSM}$ were prepared using a hydrothermal method. Typically, $0.029 \mathrm{~g}$ of $\mathrm{Cu}\left(\mathrm{NO}_{3}\right)_{2} \cdot 3 \mathrm{H}_{2} \mathrm{O}$ was dissolved in $160 \mathrm{~mL}$ of deionized water to form solution A. Then, $1.8 \mathrm{~g}$ of CTAB was dissolved in $120 \mathrm{~mL}$ of absolute ethanol, and the mixed solution was stirred for $30 \mathrm{~min}$ to form solution B. Next, solution A was added to solution $B$, and the mixed solution was stirred for $30 \mathrm{~min}$ followed by addition of $4 \mathrm{~mL}$ of TEOS. After stirring for $1 \mathrm{~h}, 8 \mathrm{~mL}$ of ammonia ( $25 \mathrm{wt} \%$ ) was added dropwise to the mixed system to form a sol. The synthesis medium was maintained under vigorous stirring for $6 \mathrm{~h}$. Then, the sol was transferred to a Teflonlined steel autoclave and heated to $100{ }^{\circ} \mathrm{C}$ for $48 \mathrm{~h}$. After natural cooling, the obtained product was filtered, washed with deionized water and dried at $100{ }^{\circ} \mathrm{C}$ for $6 \mathrm{~h}$. Finally, the crystallisation and template removal were carried out in a muffle furnace at a heating rate of $2{ }^{\circ} \mathrm{C} / \mathrm{min}$ to $550{ }^{\circ} \mathrm{C}$, which was maintained for $6 \mathrm{~h}$. In addition, the content of copper in the sample was determined by ICPOES (Optima 2000) after the sample was completely dissolved using nitric acid. By the same procedure, five samples with different copper content ( $0 \mathrm{wt} \%, 0.75 \mathrm{wt} \%, 0.93 \mathrm{wt} \%, 1.14 \mathrm{wt} \%$ and $1.55 \mathrm{wt} \%$ ) were prepared, which were designated as $\mathrm{M}_{0}, \mathrm{M}_{1}, \mathrm{M}_{2}$, $\mathrm{M}_{3}$ and $\mathrm{M}_{4}$, respectively. As a reference, iron-doped mesoporous silica microspheres (designated as $\mathrm{M}_{\mathrm{Fe}}$ ) was also synthesized as described above without the addition of the cupric nitrate but with the addition of ferric nitrate.

\subsection{Characterization}

The transmission electron microscopy (TEM) images of the samples were obtained using a JEOL-2010 TEM with an acceleration voltage of $200 \mathrm{kV}$. The scanning electron microscopy (SEM) images of the samples were obtained using a SU8020 FESEM (Hitachi). Nitrogen adsorption/desorption experiments of the samples were 
carried out at $-196{ }^{\circ} \mathrm{C}$ using a Micromeritics ASAP2000 analyzer (Micromeritics, Norcross, GA). The samples were outgassed under a vacuum at $250^{\circ} \mathrm{C}$ for $4 \mathrm{~h}$ prior to conducting measurements. The specific surface areas were calculated from the isotherms using the BET method; and the pore-size distribution was calculated using the Barrett-Joyner-Halenda (BJH) model. The powder Xray diffraction (XRD) of the samples were recorded on a ScintagXDS-2000 diffractometer with $\mathrm{Cu} \mathrm{K} \alpha$ radiation $(\lambda=1.540598 \AA$ ). The UV-vis diffuse reflectance spectroscopy (UV-vis DRS) were recorded on a Hitachi U-3900 spectrophotometer. The X-ray photoelectron spectroscopy (XPS) data was taken on an AXISUltra instrument (Kratos Analytical, UK) using monochromatic Al $\mathrm{K} \alpha$ radiation $(225 \mathrm{~W}, 15 \mathrm{~mA}, 15 \mathrm{kV})$. To compensate for surface charge effects, the binding energies were calibrated using the $\mathrm{C} 1 \mathrm{~s}$ hydrocarbon peak at $284.8 \mathrm{eV}$.

\subsection{Procedures and analysis}

Three PhACs (PHT, IBU and DP) were selected to evaluate the activity and properties of the catalyst. In a typical experiment, $50 \mathrm{~mL}$ of PhACs aqueous solution $\left(10 \mathrm{mg} \mathrm{L}^{-1}\right)$ with neutral $\mathrm{pH}$ was placed in a beaker. A given amount of catalyst with equivalent $\mathrm{Cu}(0.058 \mathrm{mM})$ was added, and the suspension was stirred at room temperature for approximately $20 \mathrm{~min}$ to establish the adsorption/ desorption equilibrium between PhACs and the catalyst. Then, a certain concentration of $\mathrm{H}_{2} \mathrm{O}_{2}$ was added to the above suspensions under continuous stirring. The optimal dosages of $\mathrm{H}_{2} \mathrm{O}_{2}(10 \mathrm{mM})$ were determined according to the best activity of PHT degradation under otherwise identical conditions (Fig. S2), and used in all the experiments unless specific illustration. Then, samples were taken at set intervals using a $1 \mathrm{~mL}$ syringe, filtered immediately through a $0.45 \mu \mathrm{m}$ Millipore filter. The filtered liquor and the solid residues on the surface of the filter were collected for further analysis. All the pollutants were analyzed by means of a 1200 series HPLC (Agilent, U.S.A.) equipped with a UV detector and a ZORBAX Eclipse $X_{D B}-C_{18}$ column $(4.6 \times 150 \mathrm{~mm}, 5 \mu \mathrm{m})$. The mobile phase was a $60 / 40 \%(\mathrm{v} / \mathrm{v})$ mixture of acetonitrile/water with a flow rate of $1 \mathrm{~mL} \mathrm{~min}{ }^{-1}$. TOC was determined by a Shimadzu TOC- $\mathrm{V}_{\mathrm{CPH}}$ analyzer. The released metallic ions from the catalysts in reaction process were determined by ICP-OES on an OPTIMA 2000 (Perkin Elmer Co., U.S.A.). The $\mathrm{H}_{2} \mathrm{O}_{2}$ concentration was determined using a DPD method according to a previously published procedure [29]. To test the stability and recyclability of the catalysts, the materials were filtered, washed with water, and dried at $100^{\circ} \mathrm{C}$. The catalysts were used in the following cycle. All information for the samples preparation and measurements of electron spin resonance (ESR), gas chromatography-mass spectrometry (GCMS), Fourier-transform infrared spectra (FTIR) and in situ Raman spectra were shown in Supporting information. Each experiment was run in triplicate. Data were the arithmetic mean of three measured values.

Table 1

Properties of the synthesized samples.

\begin{tabular}{llllll}
\hline Sample & $\begin{array}{l}\text { Cu content } \\
(\mathrm{wt} \%)\end{array}$ & $\begin{array}{l}\text { Framework } \\
\mathrm{Cu}^{\mathrm{a}}(\%)\end{array}$ & $\begin{array}{l}\text { Extraframework } \\
\mathrm{Cu}^{\mathrm{b}}(\%)\end{array}$ & $\begin{array}{l}d(100) \\
(\mathrm{nm})\end{array}$ & $\begin{array}{l}a_{0}{ }^{\mathrm{c}} \\
(\mathrm{nm})\end{array}$ \\
\hline $\mathrm{M}_{0}$ & 0 & 0 & 0 & 3.52 & 4.06 \\
$\mathrm{M}_{1}$ & 0.75 & 98.53 & 1.47 & 3.57 & 4.12 \\
$\mathrm{M}_{2}$ & 0.93 & 97.47 & 2.53 & 3.70 & 4.27 \\
$\mathrm{M}_{3}$ & 1.14 & 79.19 & 20.81 & 3.64 & 4.20 \\
$\mathrm{M}_{4}$ & 1.55 & 58.94 & 41.06 & 3.71 & 4.28 \\
\hline
\end{tabular}

a The percentages of framework species in total copper.

b The percentages of extraframework species in total copper.

c Unit cell parameter.

\section{Results and discussion}

\subsection{Characterization of catalysts}

The properties of the synthesized $\mathrm{Cu}-\mathrm{MSM}$ samples with various $\mathrm{Cu}$ contents determined by ICP-OES were included in Table 1. Fig. $1 \mathrm{a}$ and $\mathrm{b}$ shows the typical SEM images of the silica microspheres, revealing that both the pure mesoporous silica microspheres $\left(\mathrm{M}_{0}\right)$ and copper-doped mesoporous silica microspheres $\left(\mathrm{M}_{2}\right)$ were spherical with a narrow range of size distribution and an average diameter of $500 \mathrm{~nm} \pm 20 \mathrm{~nm} . \mathrm{M}_{2}$ had a more perfect spherical shape than $\mathrm{M}_{0}$, indicating that the introduction of copper to the framework of mesoporous silica was in favor of the formation of microspheres. Fig. 1c and d displays the TEM images of $\mathrm{M}_{0}$ and $\mathrm{M}_{2}$, suggesting that $\mathrm{Cu}-\mathrm{MSM}$ had a multiporous structure. The porous properties of the samples were further obtained from $\mathrm{N}_{2}$ adsorption-desorption measurements (Fig. S3). Both $\mathrm{M}_{0}$ and $\mathrm{M}_{2}$ exhibited the adsorption-desorption isotherms of type IV with hysteresis loops, large surface areas of 1063.4 and $1026.5 \mathrm{~m}^{2} \mathrm{~g}^{-1}$, and narrow pore diameters of $2.33 \mathrm{~nm}$ and $2.36 \mathrm{~nm}$, respectively, indicating that $\mathrm{Cu}-\mathrm{MSM}$ had the typical mesoporous structure. The XRD patterns of all the synthesized samples are shown in Fig. 2. In the low-angle range, all of the samples exhibited the (100) diffraction peak, which was assigned to pure mesoporous silica, indicating that the mesoporous structure did not collapse upon introduction of copper. In the high-angle XRD patterns, the broad peak at $23^{\circ}$ corresponded to amorphous silica, and no diffraction peaks of copper oxide $\left(\mathrm{CuO}_{x}\right)$ were observed in these samples, indicating that the small amounts of copper species might be highly dispersed in the structure or do not form the crystals of $\mathrm{CuO}_{x}[23]$. On the other hand, the unit cell parameter $\left(a_{0}\right)$ increased with the order of $\mathrm{M}_{0}<\mathrm{M}_{1}<\mathrm{M}_{2}$ and reached an upper limit of 4.27 when the copper content increased to $0.93 \mathrm{wt} \%\left(\mathrm{M}_{2}\right)$ in the structure of the materials as shown in Table 1 , indicating that $\mathrm{Cu}^{2+}$ was incorporated into the framework of the materials to replace $\mathrm{Si}^{4+}$ due to the larger ionic radius of $\mathrm{Cu}^{2+}$ compared to that of $\mathrm{Si}^{4+}$ [30]. However, the $a_{0}$ did not increase significantly as copper content increased to $1.14 \mathrm{wt} \%\left(\mathrm{M}_{3}\right)$ and $1.55 \mathrm{wt} \%\left(\mathrm{M}_{4}\right)$, suggesting that there existed an upper limit of the amount of copper that could be incorporated inside the framework, and a further increase in the copper content would lead to the presence of extraframework copper species.

The metallic states of the copper species in Cu-MSMs were measured semi-quantitatively by UV-vis DRS (Fig. 3). All of the samples exhibited strong absorption peaks at ca. $220 \mathrm{~nm}$ and $255 \mathrm{~nm}$, which corresponded to the charge transfer transitions of isolated $\mathrm{Cu}(\mathrm{II})$ in coordination with lattice oxygen [31,32]. This result suggested the formation of $\mathrm{Si}-\mathrm{O}-\mathrm{Cu}$ in the framework of the samples [30,33,34]. In addition, both $\mathrm{M}_{3}$ and $\mathrm{M}_{4}$ exhibited two peaks in 300 and $600-800 \mathrm{~nm}$ regions which did not appear in the spectra of $M_{1}$ and $M_{2}$, indicating that the excess copper showed the different existence state. The absorption bands at $300 \mathrm{~nm}$ corresponded to the charge transfer between the $\mathrm{Cu}(\mathrm{II})$ and oxygen in the $[\mathrm{Cu}-\mathrm{O}-\mathrm{Cu}] n$ surface species, which contributed to the extraframework copper oligomers or aggregated copper oxide clusters $[35,36]$. The broad absorption bands in the region of $600-800 \mathrm{~nm}$ were assigned to the $\mathrm{d}-\mathrm{d}$ transition of $\mathrm{Cu}(\mathrm{II})$ in the pseudo-octahedral ligand field generated by oxygen ions, indicating the presence of extraframework $\mathrm{CuO}$ particles [35]. Based on the analysis above, the distribution percentages of the framework copper and extraframework copper of different catalysts were presented in Table 1 . The copper species of $\mathrm{M}_{1}$ and $\mathrm{M}_{2}$ were primarily in the framework (approximately 98\% in the total copper), and the amount of the framework $\mathrm{Cu}$ calculated by the $\mathrm{Cu}$ contents of $\mathrm{Cu}$ MSMs multiplied by the percentages of the framework $\mathrm{Cu}$ were 

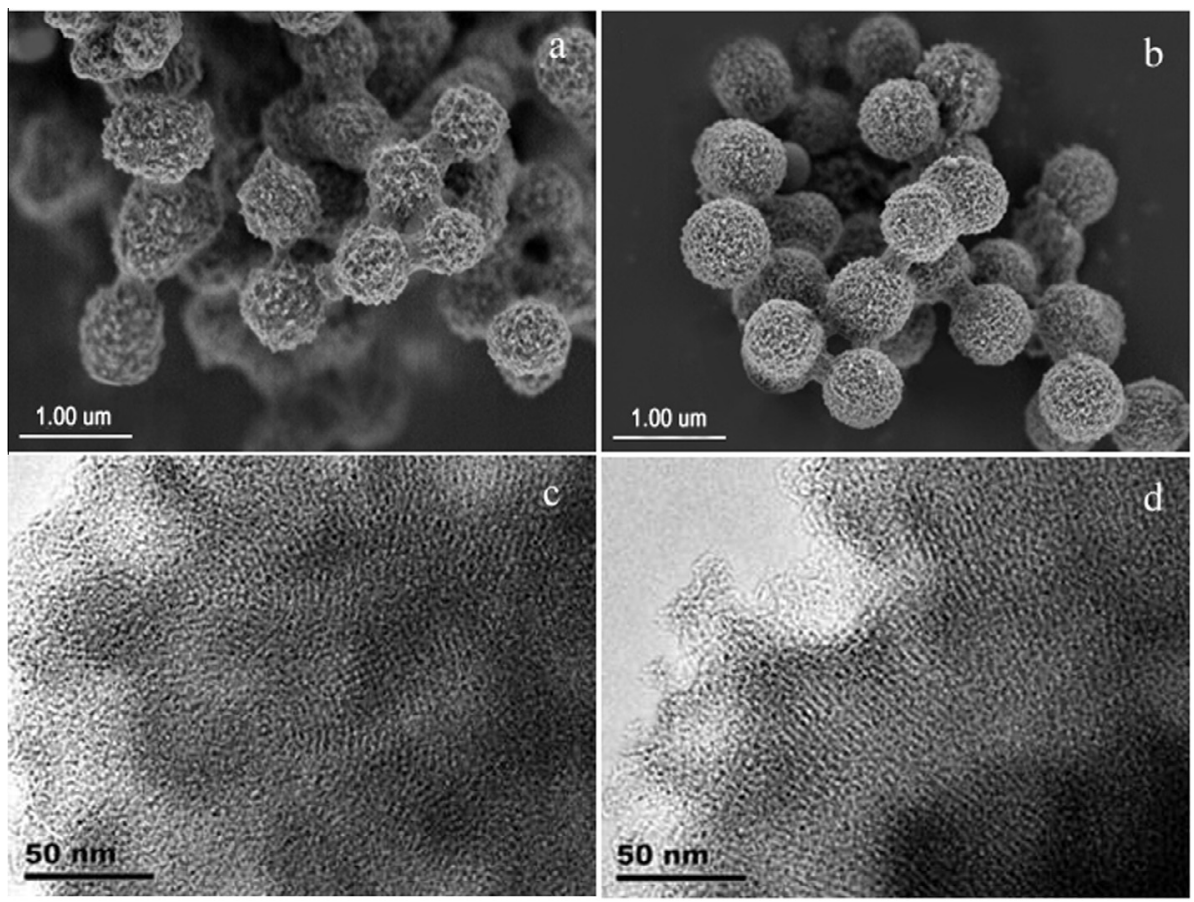

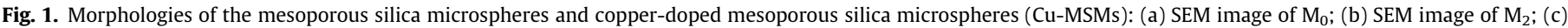
TEM image of $\mathrm{M}_{0}$; and (d) TEM image of $\mathrm{M}_{2}$.

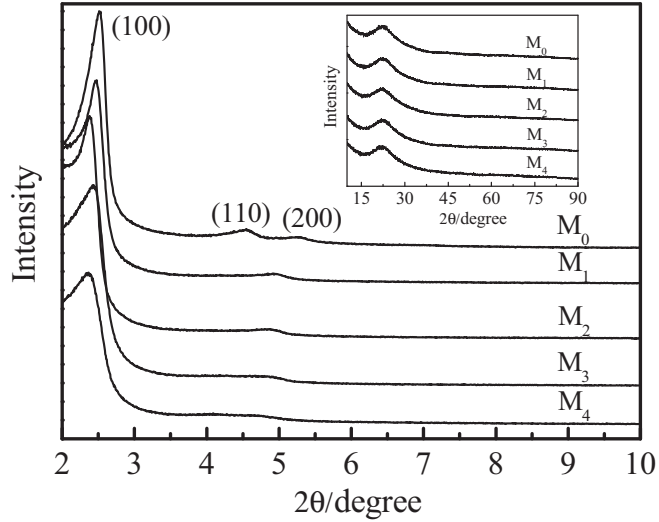

Fig. 2. XRD patterns of the synthesized samples. Insert shows the corresponding high-angle XRD patterns.

$0.74 \mathrm{wt} \%$ and $0.91 \mathrm{wt} \%$, respectively. However, the amount of the framework $\mathrm{Cu}$ in $\mathrm{M}_{3}$ and $\mathrm{M}_{4}$ were $0.90 \mathrm{wt} \%$ and $0.91 \mathrm{wt} \%$, and the amount of their extraframework $\mathrm{Cu}$ calculated by the $\mathrm{Cu}$ contents multiplied by the percentages of the extraframework $\mathrm{Cu}$ were $0.24 \mathrm{wt} \%$ and $0.64 \mathrm{wt} \%$, respectively. The results indicated that the copper species with an upper limit of $0.91 \mathrm{wt} \%$ existed in the framework of $\mathrm{Cu}-\mathrm{MSMs}$, and above the upper limit, the copper species were primarily located in the extraframework sites, which agreed with the results of XRD.

The presence of $\mathrm{Cu}(\mathrm{I})$ and $\mathrm{Cu}(\mathrm{II})$ on the surface of $\mathrm{Cu}-\mathrm{MSM}$ was confirmed using the XPS measurement, as shown in Fig. 4. The peaks of $\mathrm{M}_{2}$ corresponding to $\mathrm{Cu} 2 \mathrm{p}_{3 / 2}$ were observed at ca. 933.7 and $935.6 \mathrm{eV}$ for reduced copper species and $\mathrm{Cu}(\mathrm{II})$ [37], respectively. $\mathrm{Cu}(\mathrm{II})$ was also observed due to the appearance of a shakeup satellite line at ca. $943.9 \mathrm{eV}$. The Auger parameter at $1847.8 \mathrm{eV}$ confirmed the existence of $\mathrm{Cu}(\mathrm{I})$. It should be noted that the $\mathrm{Cu} 2 \mathrm{p}_{3 / 2}$ binding energy $(935.6 \mathrm{eV}$ ) for $\mathrm{Cu}(\mathrm{II})$ was much higher than that for pure $\mathrm{CuO}(\sim 933.8 \mathrm{eV})$ [38], indicating that the high electron affinity of silicon resulted in the movement of electrons from copper to silicon [39]. This evidence further supported the formation of $\mathrm{Si}-\mathrm{O}-\mathrm{Cu}$ in the framework of the samples. Similarly, $\mathrm{Cu}(\mathrm{I})$ and $\mathrm{Cu}(\mathrm{II})$ were also detected on the surface of $\mathrm{M}_{4}$. In addition, the peak fitting of the $\mathrm{O} 1 \mathrm{~s}$ spectra for $\mathrm{M}_{2}$ and $\mathrm{M}_{4}$ were shown in Fig. S4. The first peak, $\mathrm{P}_{1}$ in the 532.5$533.5 \mathrm{eV}$ range was the $\mathrm{O} 1 \mathrm{~s}$ peak that characterized the lattice oxygen; and the second peak, $\mathrm{P}_{2}$ in the range of $533.5-534.5 \mathrm{eV}$ that denoted $\mathrm{O} 1 \mathrm{~s}$ lateral structure. The oxygen vacancy concentration could be calculated from the variation of area ratio $R$ of the two $O 1 \mathrm{~s}$ peaks [40]. The value of $R\left(\mathrm{M}_{2}\right) 7.78$ was higher than that of $R\left(\mathrm{M}_{4}\right) 6.42$, indicating that the oxygen vacancy concentration of $\mathrm{M}_{4}$ was higher than that of $\mathrm{M}_{2}$, which was attributed to the extraframework copper species in $\mathrm{M}_{4}$.

\subsection{Degradation of PhACs in Cu-MSMs suspensions with $\mathrm{H}_{2} \mathrm{O}_{2}$}

According to the given amount of catalyst with equivalent $\mathrm{Cu}$ $(0.058 \mathrm{mM})$, the Fenton-like catalytic activity of the different catalysts were evaluated by the degradation of PHT with $\mathrm{H}_{2} \mathrm{O}_{2}$ as shown in Fig. 5. During the adsorption/desorption equilibrium, only about $10 \%$ of the PHT were adsorbed for all the samples. After adding $\mathrm{H}_{2} \mathrm{O}_{2}$, no significant degradation of PHT was observed in the $\mathrm{M}_{0}$ suspension, and only $22.6 \%$ of PHT was degraded in the $\mathrm{M}_{\mathrm{Fe}}$ (iron-doped mesoporous silica microspheres) suspension within 120 min. However, PHT was substantially degraded in the $\mathrm{Cu}-\mathrm{MSMs}$ suspensions. The PHT conversion at $60 \mathrm{~min}$ followed the order of $\mathrm{M}_{0} \quad(8.4 \%)<\mathrm{M}_{\mathrm{Fe}} \quad(13.0 \%) \ll \mathrm{M}_{4} \quad(80.0 \%)<\mathrm{M}_{3}$ $(83.4 \%)<\mathrm{M}_{1}(94.4 \%)<\mathrm{M}_{2}(96.0 \%)$. The TOC removal at $180 \mathrm{~min}$ followed the order of $\mathrm{M}_{4}(43.7 \%)<\mathrm{M}_{3}(48.3 \%)<\mathrm{M}_{1}(56.3 \%)<\mathrm{M}_{2}$ (62.6\%). According to the previously described method (SI) [41], the utilization efficiency of $\mathrm{H}_{2} \mathrm{O}_{2}$ was defined as the ratio of the stoichiometric amount of $\mathrm{H}_{2} \mathrm{O}_{2}$ for the mineralization of pollutants to the total amount of the really consumed $\mathrm{H}_{2} \mathrm{O}_{2}$ in the reaction, and this value followed the order of $\mathrm{M}_{4}(63.4 \%)<\mathrm{M}_{3}(71.9 \%)<\mathrm{M}_{1}$ $(82.9 \%)<\mathrm{M}_{2}(84.0 \%)$ at the time of the initial PHT disappeared. $\mathrm{M}_{1}$ and $\mathrm{M}_{2}$ where the copper species were primarily in the 

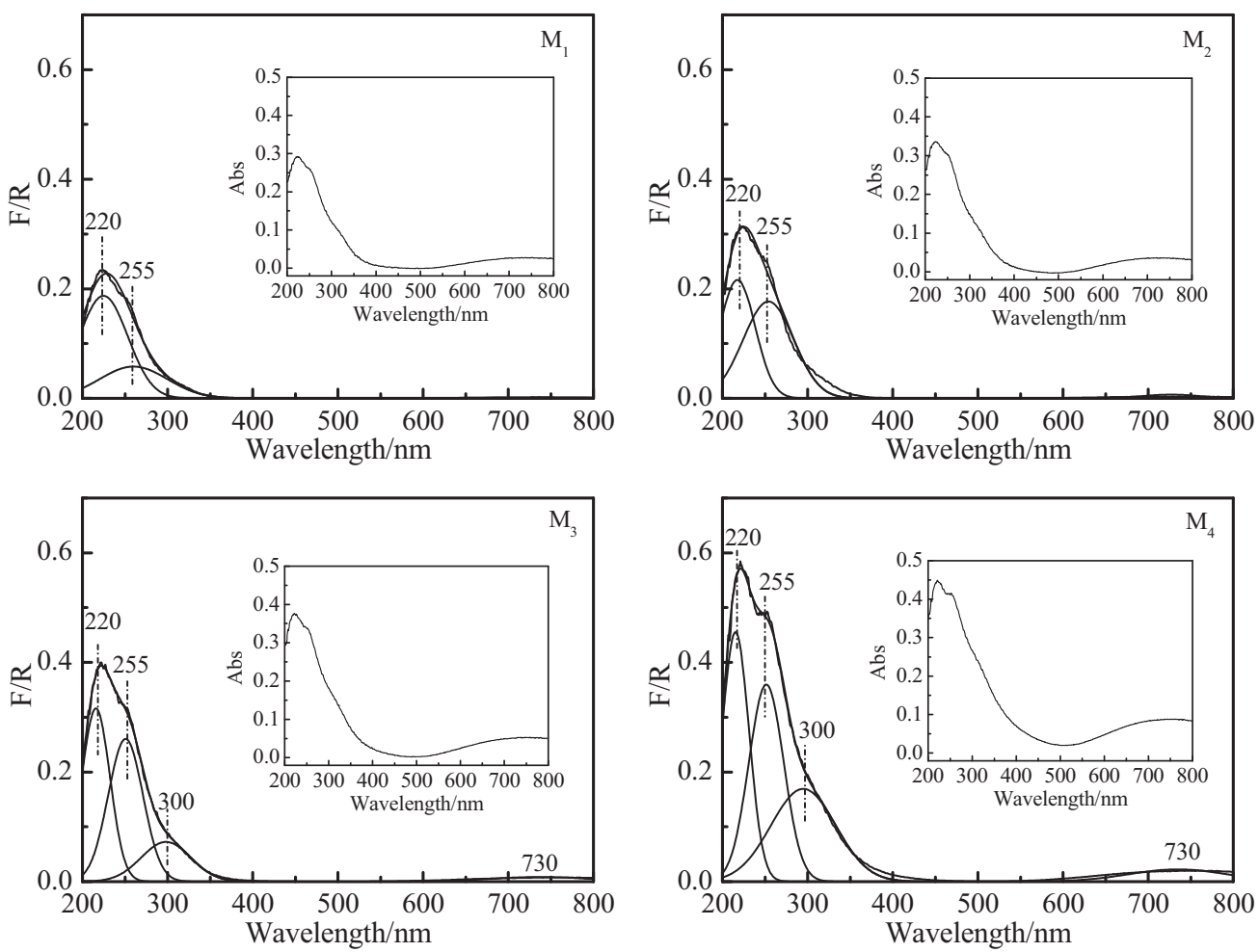

Fig. 3. Deconvoluted subbands in the UV-vis DRS of the synthesized samples with different amounts of copper. Inset shows the relative UV-vis DRS.
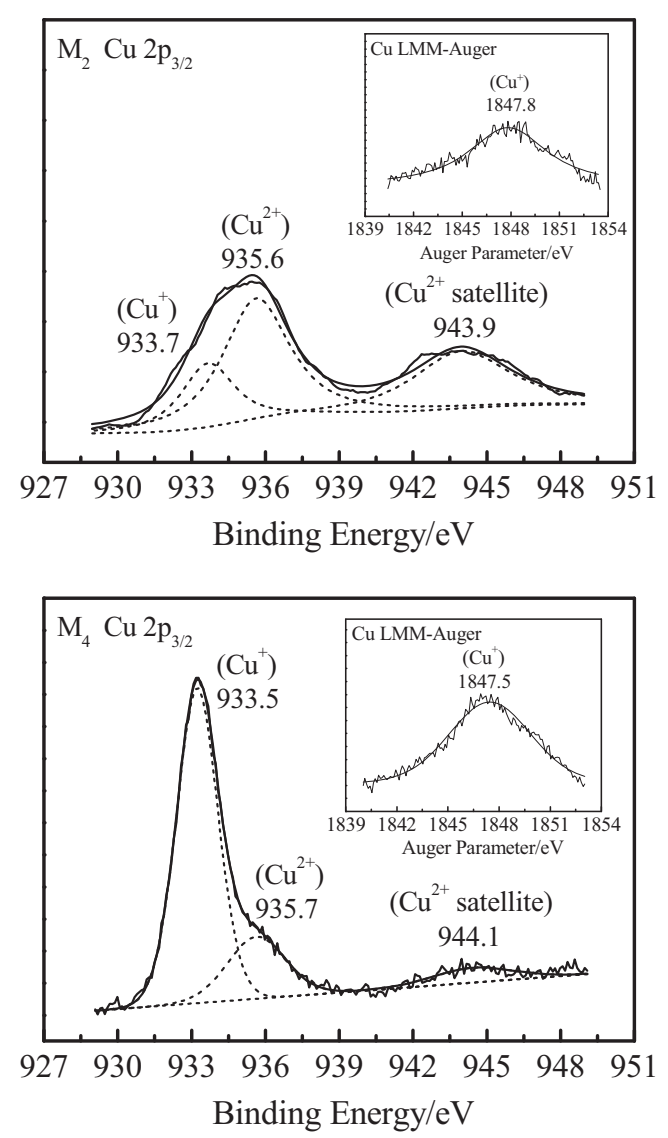

Fig. 4. XPS spectra in $\mathrm{Cu} 2 \mathrm{p}_{3 / 2}$ for $\mathrm{M}_{2}$ and $\mathrm{M}_{4}$. Inset shows the LMM X-ray induced Auger parameter for the corresponding sample. framework exhibited the best activity and the highest utilization efficiency of $\mathrm{H}_{2} \mathrm{O}_{2}$, while $\mathrm{M}_{3}$ and $\mathrm{M}_{4}$ with considerable extraframework copper species exhibited lower activity and utilization efficiency of $\mathrm{H}_{2} \mathrm{O}_{2}$.

In addition, the degradation of other two PhACs (IBU and DP) had the same regularities (Fig. 6). $\mathrm{M}_{2}$ exhibited the best activity during IBU and DP degradation and they could be completely converted within $120 \mathrm{~min}$ and $90 \mathrm{~min}$, respectively, while $\mathrm{M}_{3}$ and $\mathrm{M}_{4}$ exhibited a lower activity. At $180 \mathrm{~min}$ of reaction, the TOC removal of IBU and DP in $\mathrm{M}_{2}$ suspensions were $61.3 \%$ and $64.5 \%$, respectively, while in $\mathrm{M}_{3}$ and $\mathrm{M}_{4}$ suspensions, the TOC removal were below $50 \%$. The utilization efficiency of $\mathrm{H}_{2} \mathrm{O}_{2}$ at the time of the initial IBU and DP disappeared followed the order of $\mathrm{M}_{4}(58.1 \%)<\mathrm{M}_{3}$ $(72.9 \%)<\mathrm{M}_{2}$ (83.7\%), and $\mathrm{M}_{4}(59.2 \%)<\mathrm{M}_{3}(64.3 \%)<\mathrm{M}_{2}(80.8 \%)$, respectively. These results suggested that the copper species in the framework were more efficient than the ones in the

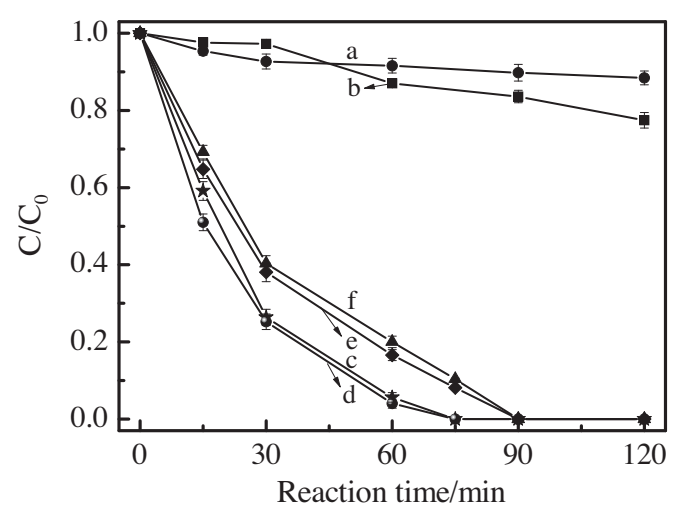

Fig. 5. Fenton-like degradation of PHT under different suspensions: (a) $M_{0}$ $\left(0.4 \mathrm{~g} \mathrm{~L}^{-1}\right.$ ); (b) $\mathrm{M}_{\mathrm{Fe}}$; (c) $\mathrm{M}_{1}$; (d) $\mathrm{M}_{2}$; (e) $\mathrm{M}_{3}$; and (f) $\mathrm{M}_{4}$. (Initial PHT $10 \mathrm{mg} \mathrm{L}^{-1}$, initial $\mathrm{H}_{2} \mathrm{O}_{2} 10 \mathrm{mmol} \mathrm{L}^{-1}$, equivalent metal $0.058 \mathrm{mmol} \mathrm{L}^{-1}$.) 

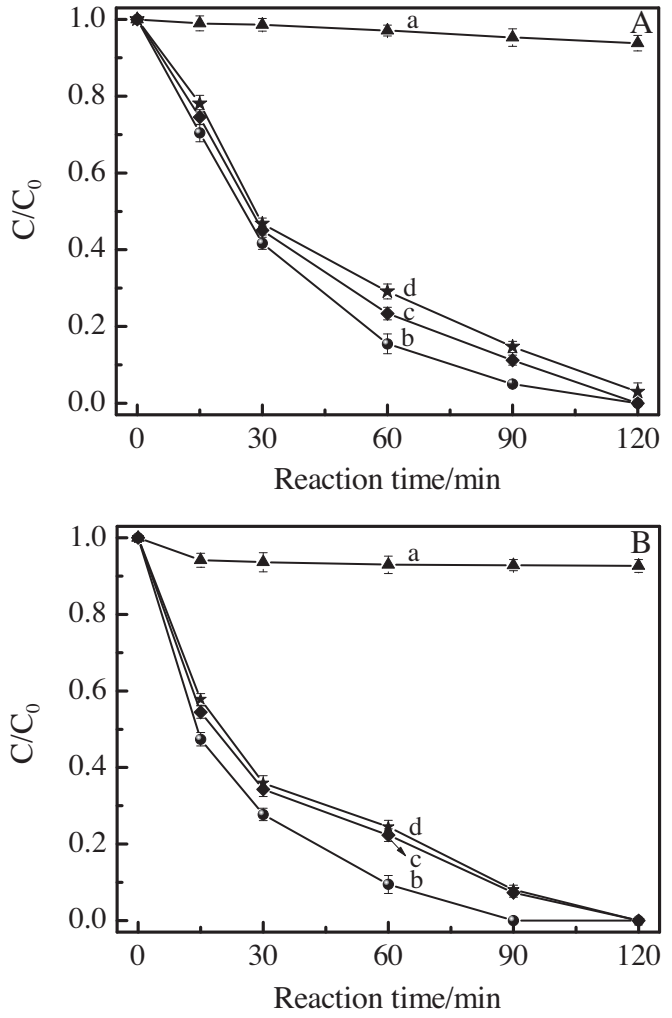

Fig. 6. Fenton-like degradation of IBU (A) and DP (B) under different suspensions: (a) $\mathrm{M}_{0}\left(0.4 \mathrm{~g} \mathrm{~L}^{-1}\right.$ ); (b) $\mathrm{M}_{2}$; (c) $\mathrm{M}_{3}$; and (d) $\mathrm{M}_{4}$. (Initial PhACs $10 \mathrm{mg} \mathrm{L}^{-1}$, initial $\mathrm{H}_{2} \mathrm{O}_{2}$ $10 \mathrm{mmol} \mathrm{L}^{-1}$, equivalent $\mathrm{Cu} 0.058 \mathrm{mmol} \mathrm{L}^{-1}$.)

extraframework of Cu-MSMs for the Fenton-like degradation of PhACs.

The stability tests of Cu-MSMs were carried out by PHT degradation. At the end of reaction, the amount of copper leaching had the order of $\mathrm{M}_{1} \quad\left(0.16 \mathrm{mg} \mathrm{L}^{-1}\right)<\mathrm{M}_{2} \quad\left(0.17 \mathrm{mg} \mathrm{L}^{-1}\right)<\mathrm{M}_{3}$ $\left(0.40 \mathrm{mg} \mathrm{L}^{-1}\right)<\mathrm{M}_{4}\left(0.47 \mathrm{mg} \mathrm{L}^{-1}\right)$, suggesting that the extraframework copper species leached into the solution more easily than the framework copper species during the Fenton-like reactions. To investigate the effect of dissolved metal ions on degradation, a homogeneous experiment using $0.2 \mathrm{mg} \mathrm{L}^{-1} \mathrm{Cu}(\mathrm{II})$ with $10 \mathrm{mM}$ $\mathrm{H}_{2} \mathrm{O}_{2}$ was conducted and got only $6.5 \%$ of the TOC abatement within $180 \mathrm{~min}$, indicating that the observed PhACs removals in the $M_{1}$ and $M_{2}$ suspensions were mainly attributed to heterogeneous catalytic reactions. In addition, the activity of $\mathrm{M}_{2}$ did not markedly decrease after six successive cycles of degradation testing (Fig. S5), and it was observed that the $\mathrm{Cu}(\mathrm{II})$ leaching from Cu-MSMs became fewer and fewer, less than $0.1 \mathrm{mg} \mathrm{L}^{-1}$ with the cycling times. The results suggested that $\mathrm{M}_{2}$ was an effective and stable catalyst for heterogeneous Fenton reactions.

\subsection{Role of the framework copper species in Cu-MSMs on Fenton-like process}

A series of $\mathrm{H}_{2} \mathrm{O}_{2}$ decomposition experiments were performed in the presence of Cu-MSMs without PhACs (Fig. 7) where $\mathrm{H}_{2} \mathrm{O}_{2}$ finally decomposed into $\mathrm{O}_{2}$. The decomposition rate had the order of $M_{1}<M_{2}<M_{3}<M_{4}$, suggesting that these catalysts exhibited the opposite reactivity for the decomposition of $\mathrm{H}_{2} \mathrm{O}_{2}$ compared to the degradation of $\mathrm{PhACs}$, and the rate of $\mathrm{H}_{2} \mathrm{O}_{2}$ disappearance increased with increasing the ratio of extraframework copper in $\mathrm{Cu}-\mathrm{MSMs} . \mathrm{M}_{2}$ exhibited the highest catalytic activity toward the $\mathrm{PhACs}$ degradation and lower activity for the $\mathrm{H}_{2} \mathrm{O}_{2}$ decomposition,

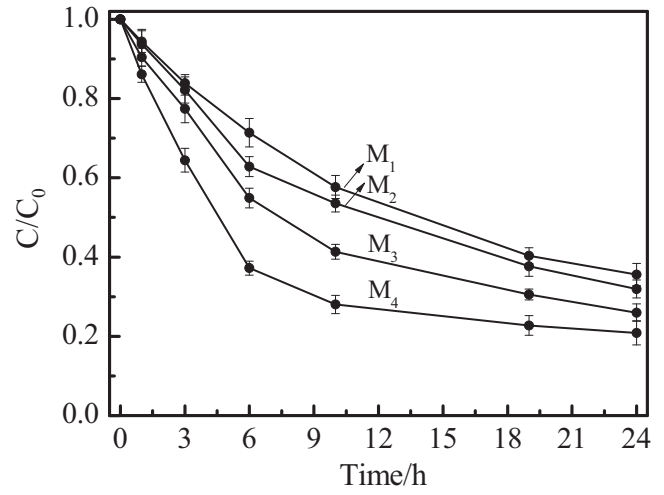

Fig. 7. $\mathrm{H}_{2} \mathrm{O}_{2}$ decomposition under different suspensions. (Initial $\mathrm{H}_{2} \mathrm{O}_{2} 10 \mathrm{mmol} \mathrm{L}^{-1}$, equivalent $\mathrm{Cu} 0.058 \mathrm{mM}$.)

indicating that the framework copper species in Cu-MSMs were extremely selective for promoting Fenton chemistry with minor spurious decomposition of $\mathrm{H}_{2} \mathrm{O}_{2}$ to $\mathrm{O}_{2}$. Since oxygen vacancies took part in the decomposition of $\mathrm{H}_{2} \mathrm{O}_{2}$ into $\mathrm{O}_{2}$ [42], $\mathrm{M}_{4}$ showed the highest activity for the decomposition of $\mathrm{H}_{2} \mathrm{O}_{2}$ due to its higher concentration of oxygen vacancies, which were produced by the extraframework copper species in the form of aggregated copper oxide clusters. In our previous study [43], no ${ }^{\circ} \mathrm{OH}$ formation was determined with the decomposition of $\mathrm{H}_{2} \mathrm{O}_{2}$ in aqueous $\mathrm{CuO}_{x^{-}}$ $\mathrm{H}_{2} \mathrm{O}_{2}$ suspension, confirming this mechanism.

The ESR spin-trapping technique (with BMPO) was employed to detect the reactive oxygen species (ROS) involved in the suspension of the catalyst with $\mathrm{H}_{2} \mathrm{O}_{2}$. As shown in Fig. 8, no significant signals were attributed to $\mathrm{OH}$ in the control experiments without catalyst (curve a) or in the $\mathrm{M}_{0}$ aqueous dispersion (curve $\mathrm{b}$ ), while four characteristic peaks of BMPO-OH were observed in the aqueous dispersion of $\mathrm{Cu}-\mathrm{MSMs}$ with $\mathrm{H}_{2} \mathrm{O}_{2}$ (curve c-f). The intensities of these peaks in the suspension with $\mathrm{H}_{2} \mathrm{O}_{2}$ had the sequence: $\mathrm{M}_{2}>\mathrm{M}_{1}>\mathrm{M}_{3}>\mathrm{M}_{4}$. The formation of $\mathrm{HO}_{2} / \mathrm{O}_{2}^{-}$radicals was also detected in methanol, and the similar rule with the formation of - $\mathrm{OH}$ radicals was found in the systems. The result was in agreement with the catalytic activity of $\mathrm{Cu}-\mathrm{MSM}$ for the degradation of PhACs, indicating that $\mathrm{H}_{2} \mathrm{O}_{2}$ was more effectively converted to $\cdot \mathrm{OH}$ and $\mathrm{HO}_{2} / \mathrm{O}_{2}^{-}$radicals at the interface of $\mathrm{M}_{2}$ where the copper species were primarily in the framework of $\mathrm{Cu}-\mathrm{MSM}$.

\subsection{Role of the intermediates from PhACs degradation in $M_{2}$ suspension}

GC-MS was used to monitor the generation of reaction intermediates during the degradation of PhACs in $\mathrm{M}_{2}$ suspension. All of the identified compounds were unequivocally identified using the NIST98 library database with fit values higher than $90 \%$. Table S1a shows the main intermediates from the degradation of PHT at 20 min reaction time. 5 aromatic products, including 4hydroxybenzoic acid, 2,4-dihydroxybenzoic acid, 2-(3,4-dihydroxyphenyl)-2-hydroxyacetic acid, 2-(3,4-dihydroxyphenyl)-2-hydroxyethylamine and PHT, and 2 low-molecule weight organic acids were detected on the surface of $\mathrm{M}_{2}$, whereas 6 alcohols, 2 aromatic products including benzoic acid and PHT were detected in the solution. These results indicated that the degradation of PHT and intermediates predominantly occurred on the surface of $\mathrm{M}_{2}$. For other two PhACs, there were almost the same regularities of the intermediates distribution as PHT degradation. As shown in Table S1b and c, except for some low-molecule weight organics, several aromatic products including 2-(3,4-dihydroxyphenyl)-2hydroxyacetic acid, benzoic acid, 4-hydroxybenzoic acid, 2,4- 

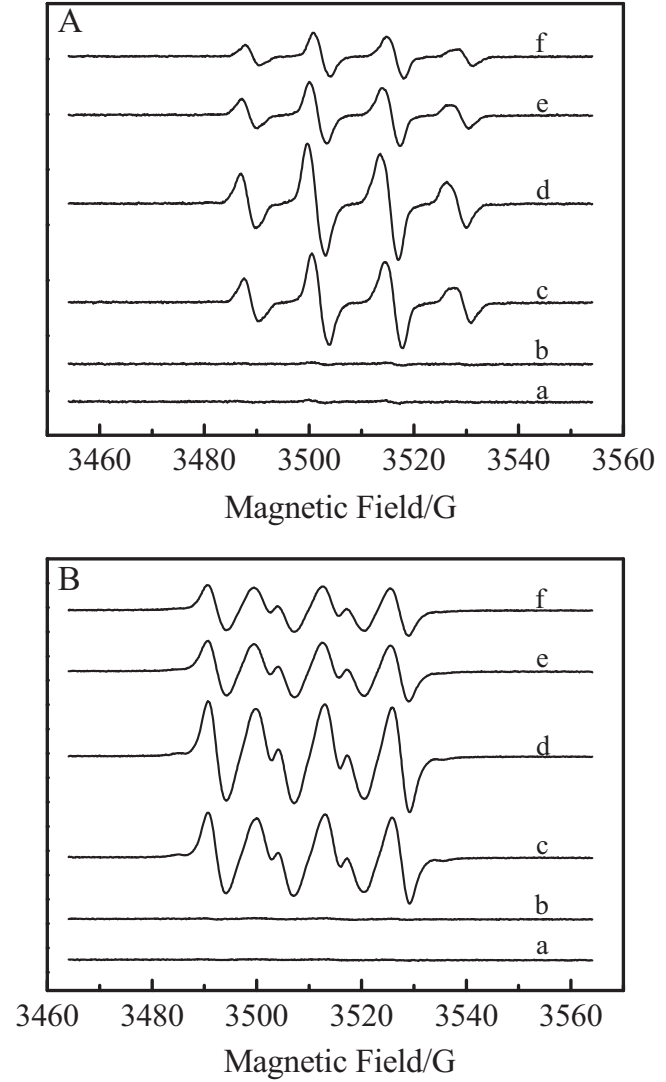

Fig. 8. BMPO spin trapping ESR spectra recorded at ambient temperature for the synthesized samples as catalysts (A) in an aqueous dispersion for $\mathrm{BMPO}-{ }^{-} \mathrm{OH}$ and (B) in a methanol dispersion for BMPO- $\mathrm{HO}_{2} / \mathrm{O}_{2}^{--}$: (a) $\mathrm{H}_{2} \mathrm{O}_{2}$; (b) $\mathrm{H}_{2} \mathrm{O}_{2}$ with $\mathrm{M}_{0}$; (c) $\mathrm{H}_{2} \mathrm{O}_{2}$ with $\mathrm{M}_{1}$; (d) $\mathrm{H}_{2} \mathrm{O}_{2}$ with $\mathrm{M}_{2}$; (e) $\mathrm{H}_{2} \mathrm{O}_{2}$ with $\mathrm{M}_{3}$; and (f) $\mathrm{H}_{2} \mathrm{O}_{2}$ with $\mathrm{M}_{4}$.

dihydroxybenzoic acid, 1,4-benzenedicarboxylic acid and diphenylmethanol were detected during the degradation of IBU and DP, respectively. These aromatic intermediates were found only on the surface of $\mathrm{M}_{2}$, and were not found in the solutions, except for benzoic acid, indicating that the aromatic intermediates were predominantly adsorbed on the surface of the catalyst. Moreover, most of the intermediates are acids and alcohols, and more likely to be further treatment, indicating that the deleterious effect for the environment of the initial PhACs were significantly weakened. Because the tested compounds showed similar degradation courses, PHT was used in the following investigation unless specified otherwise.

To elucidate the surface reaction process, the samples of PHT, $\mathrm{M}_{0}$ and $\mathrm{M}_{2}$ from different reaction times were filtered and dried for FTIR measurement (Fig. 9). The spectra of $\mathrm{M}_{0}$ displayed a wide absorption band at $3335 \mathrm{~cm}^{-1}$, ascribed to the stretching vibrations of $\mathrm{OH}[v(\mathrm{OH})]$ on the surface of $\mathrm{M}_{0}$ [23]. With incorporating framework copper species $\left(\mathrm{M}_{2}\right)$, the intensity of the band significantly increased, indicating that $v(\mathrm{OH})$ was closely related to the framework copper species. According to Tamura et al. [44], metal oxide species in aqueous solution could form surface hydroxyl groups by dissociative chemisorptions of water molecules. The incorporation of framework copper in mesoporous silica increased the concentration of the surface unsaturated $\mathrm{Cu}$ centers, increasing the intensity of $v(\mathrm{OH})$. For PHT compound, the absorption bands at 3271 and $3207 \mathrm{~cm}^{-1}$ ascribed to the stretching vibration of $\mathrm{N}-\mathrm{H}$, the band at 1774 and $1718 \mathrm{~cm}^{-1}$ were assigned to the stretching vibration of $\mathrm{C}=\mathrm{O}$, and the bands at 1448 and $1402 \mathrm{~cm}^{-1}$ were assigned to the skeleton vibration of aromatic rings [45]. There were no significant changes between the spectra of $\mathrm{M}_{2}$ used after

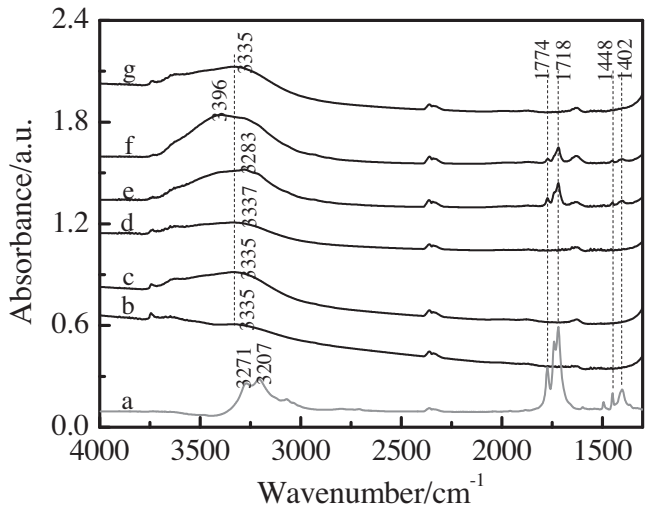

Fig. 9. FTIR spectra for various samples: (a) PHT; (b) $M_{0}$; (c) fresh $M_{2}$; (d) $M_{2}$ used after 20 min adsorption of PHT; (e) $\mathrm{M}_{2}$ used after 20 min Fenton reaction of PHT; (f) $\mathrm{M}_{2}$ used after 60 min Fenton reaction of PHT; and (g) $\mathrm{M}_{2}$ used after 300 min Fenton reaction of $\mathrm{PHT}$.

20 min adsorption of PHT and the spectra of fresh $\mathrm{M}_{2}$, indicating that PHT was not copiously adsorbed on the surface of $\mathrm{M}_{2}$, due to no $-\mathrm{OH}$ or $-\mathrm{COOH}$ existing in the structure of PHT. However, after adding $\mathrm{H}_{2} \mathrm{O}_{2}$ and maintaining Fenton-like reaction $20 \mathrm{~min}$, the intensity of the band of $v(\mathrm{OH})$ further increased and the centroid of this band shifted to $3283 \mathrm{~cm}^{-1}$. According to the result of GC-MS measurement, many phenolic intermediates, such as 4-hydroxybenzoic acid, 2,4-dihydroxybenzoic acid and 2-(3,4dihydroxyphenyl)-2-hydroxyacetic acid, were on the surface of $\mathrm{M}_{2}$ at this time. The increase of the $-\mathrm{OH}$ group on the surface caused the enhancement of the band of $v(\mathrm{OH})$. The shifted of this band was contributed by the deprotonation of the phenolic $\mathrm{OH}$ group of the intermediates and different surroundings in the first coordination sphere of the $\mathrm{Cu}^{2+}[45]$. This result indicated that the phenolic intermediates complexed with the surface $\mathrm{Cu}$ of $\mathrm{M}_{2}$ by $\sigma$ bonding to the lone pairs of oxygen atom of the phenolic OH group, namely, $\equiv$ Cu-ligands complexes [46]. The appearance of the organic absorption bands at 1774, 1718, 1448 and $1402 \mathrm{~cm}^{-1}$ validated this result. Afterwards, the band of $v(\mathrm{OH})$ changed into $3396 \mathrm{~cm}^{-1}$ at $60 \mathrm{~min}$ Fenton-like reaction and the organic absorption bands between 1400 and $1800 \mathrm{~cm}^{-1}$ weakened, suggesting that the organic pollutants were continuously degraded and the new aromatic intermediates adsorbed on the catalyst, forming new $\equiv \mathrm{Cu}$-ligands complexes, leading to the continuous change of the chemical surroundings. After 300 min reaction, all bands for organic compound disappeared, the band of $v(\mathrm{OH})$ shifted to $3335 \mathrm{~cm}^{-1}$ again, indicating that the $\equiv \mathrm{Cu}$-ligands complex completely disappeared with the degradation of the organics.

Furthermore, the interaction processes among PHT, $\mathrm{M}_{2}$ and $\mathrm{H}_{2} \mathrm{O}_{2}$ were observed by in situ Raman spectra. As shown in Fig. 10 , no any special band appeared in the $\mathrm{M}_{2}$ suspension, while two bands at 475 and $820 \mathrm{~cm}^{-1}$ appeared in the $\mathrm{PHT} / \mathrm{M}_{2}$ suspension, which were assigned to the ring wagging and aromatic $\mathrm{C}-\mathrm{H}$ twisting of PHT, respectively [47]. The spectra of the $\mathrm{M}_{2} / \mathrm{H}_{2} \mathrm{O}_{2}$ suspension displayed a significant peak at $880 \mathrm{~cm}^{-1}$ associated with the $\mathrm{O}-\mathrm{O}$ stretching vibration [48], indicating that $\mathrm{H}_{2} \mathrm{O}_{2}$ was physisorbed onto the channel in $\mathrm{M}_{2}$. In the $\mathrm{PHT} / \mathrm{M}_{2} / \mathrm{H}_{2} \mathrm{O}_{2}$ suspension, the bands at 475 and $820 \mathrm{~cm}^{-1}$ did not appear, indicating that the structure of PHT was destroyed by Fenton-like process. The band at $880 \mathrm{~cm}^{-1}$ weakened and a new organic band at $578 \mathrm{~cm}^{-1}$ ascribed to $\mathrm{C}-\mathrm{O}$ rocking appeared [47], indicating that there was a competitive adsorption between $\mathrm{H}_{2} \mathrm{O}_{2}$ and the generated intermediates on the surface of $\mathrm{M}_{2}$ during the Fenton-like process.

Moreover, it was found that the surface concentration ratio of $\mathrm{Cu}^{+}$to $\mathrm{Cu}^{2+}$ was approximately 3.2:1 on the surface of $\mathrm{M}_{2}$ after 


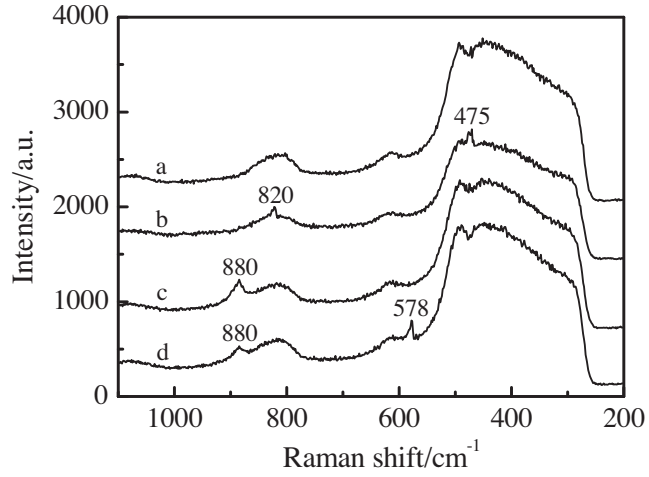

Fig. 10. In situ Raman spectra for various suspensions: (a) $\mathrm{M}_{2}$; (b) $\mathrm{PHT} / \mathrm{M}_{2}$; (c) $\mathrm{M}_{2} /$ $\mathrm{H}_{2} \mathrm{O}_{2}$; and (d) $\mathrm{PHT} / \mathrm{M}_{2} / \mathrm{H}_{2} \mathrm{O}_{2}$.

60 min of reaction during the PHT degradation, more than the 2:1 ratio before the reaction by XPS analysis (Fig. S6). The results suggested that the interaction of $\equiv \mathrm{Cu}$-ligands and $\mathrm{H}_{2} \mathrm{O}_{2}$ promoted the generation of $\mathrm{Cu}(\mathrm{I})$, overcoming the rate-limiting step of the reduction of $\mathrm{M}^{(n+m)+}$ to $\mathrm{M}^{n+}$ in Fenton-like process and accelerating the $\mathrm{Cu}(\mathrm{II}) / \mathrm{Cu}(\mathrm{I})$ cycles on the surface of $\mathrm{Cu}-\mathrm{MSM}$ sor the degradation of PhACs.

On the basis of all the above information, a possible interaction process among the framework copper species of $\mathrm{Cu}-\mathrm{MSMs}$, PhACs and $\mathrm{H}_{2} \mathrm{O}_{2}$ was proposed. During the Fenton-like catalytic degradation of PhACs, $\mathrm{H}_{2} \mathrm{O}_{2}$ was reduced by $\mathrm{Cu}(\mathrm{I})$ to generate $\cdot \mathrm{OH}$ and $\mathrm{Cu}(\mathrm{II})$ [49]. The hydrocarbon groups on the aromatic ring of PhACs were firstly attacked by $\mathrm{OH}$ to form benzoic acid. Then the hydroxylation reaction occurred on the aromatic ring at the para/ortho-position of the carboxyl group to form monohydroxy or dihydroxy aromatic substances, such as 4-hydroxybenzoic acid, 2,4-dihydroxybenzoic acid and 2-(3,4-dihydroxyphenyl)-2-hydroxyacetic acid. Most of produced phenolic intermediates were adsorbed on the surface of Cu-MSMs, complexing with the framework $\equiv \mathrm{Cu}$ (II) species, forming $\equiv \mathrm{Cu}$-ligands. $\equiv \mathrm{Cu}$-ligands then interacted with $\mathrm{H}_{2} \mathrm{O}_{2}$, enhanced the reduction rate of $\equiv \mathrm{Cu}$ (II), resulting in the more $\equiv \mathrm{Cu}(\mathrm{I})$ production, and consequently accelerated the $\mathrm{Cu}(\mathrm{II}) / \mathrm{Cu}(\mathrm{I})$ cycles on the surface of the catalyst, leading to more ${ }^{\circ} \mathrm{OH}$ generation for the PhACs oxidation.

\section{Conclusions}

$\mathrm{Cu}-\mathrm{MSM}$ s with the coexistence of $\mathrm{Cu}(\mathrm{I})$ and $\mathrm{Cu}(\mathrm{II})$ were synthesized by a hydrothermal method. The copper species with an upper limit of $0.91 \mathrm{wt} \%$ existed in the framework of Cu-MSMs, and above the upper limit the copper species were primarily located in the extraframework sites, leading to more oxygen vacancies on the surface of $\mathrm{Cu}-\mathrm{MSM}$ s. $\mathrm{M}_{2}$ with $0.93 \mathrm{wt} \%$ of $\mathrm{Cu}$, possessing the maximum framework copper content, exhibited the highest catalytic efficiency and stability for the degradation of PhACs in the presence of $\mathrm{H}_{2} \mathrm{O}_{2}$ under neutral condition. In the $\mathrm{M}_{2} / \mathrm{H}_{2} \mathrm{O}_{2}$ system, the conversion of PHT, IBU and DP could reach $100 \%$ within $75 \mathrm{~min}$, $120 \mathrm{~min}$ and $90 \mathrm{~min}$, respectively; and the leaching of $\mathrm{Cu}$ were below $0.2 \mathrm{mg} \mathrm{L}^{-1}$, much lower than the EU directives $\left(<2 \mathrm{mg} \mathrm{L}^{-1}\right)$ and USA regulations $\left(<1.3 \mathrm{mg} \mathrm{L}^{-1}\right)$. During the heterogeneous Fenton-like process, the framework $\equiv \mathrm{Cu}(\mathrm{I})$ in $\mathrm{Cu}-\mathrm{MSM}$ s primarily converted $\mathrm{H}_{2} \mathrm{O}_{2}$ into ${ }^{\circ} \mathrm{OH}$, and $\equiv \mathrm{Cu}(\mathrm{I})$ was oxidized to $\equiv \mathrm{Cu}(\mathrm{II})$ by $\mathrm{H}_{2} \mathrm{O}_{2}$ in the $\mathrm{H}_{2} \mathrm{O}_{2}$ reduction semi-reaction. Meanwhile, in the $\mathrm{H}_{2} \mathrm{O}_{2}$ oxidation semi-reaction, most of produced phenolic intermediates were adsorbed on the surface of Cu-MSMs, complexing with the framework $\equiv \mathrm{Cu}(\mathrm{II})$, forming $\equiv \mathrm{Cu}$-ligands. $\equiv \mathrm{Cu}$-ligands then interacted with $\mathrm{H}_{2} \mathrm{O}_{2}$ and enhanced the reduction rate of the framework $\equiv \mathrm{Cu}(\mathrm{II})$, resulting in the more $\equiv \mathrm{Cu}(\mathrm{I})$ production, overcoming the rate-limiting step of the reduction of $\mathrm{M}^{(n+m)+}$ to $\mathrm{M}^{n+}$ in Fenton-like process; consequently accelerated the $\mathrm{Cu}(\mathrm{II}) / \mathrm{Cu}(\mathrm{I})$ cycles on the surface of the catalyst, leading to more $\mathrm{OH}$ generation for the PhACs oxidation. The synergic effect of generated ligands and the framework copper species in the mesoporous silica microspheres resulted in the enhanced catalytic activity of Cu-MSMs under neutral condition. Although the $\mathrm{Cu}-\mathrm{li}-$ gand complexes-associated mechanism needs further in-depth study, these results are encouraging for the rational design of new heterogeneous Fenton catalysts and the application of ligands-driven Fenton process under neutral condition.

\section{Acknowledgement}

This work was supported by the National Natural Science Foundation of China (Grant Nos. 21407165, 21125731, 51138009, 51278527).

\section{Appendix A. Supplementary data}

Supplementary data associated with this article can be found, in the online version, at http://dx.doi.org/10.1016/j.cej.2015.03.137.

\section{References}

[1] D.W. Kolpin, E.T. Furlong, M.T. Meyer, E.M. Thurman, S.D. Zaugg, L.B. Barber, H.T. Buxton, Pharmaceuticals, hormones, and other organic wastewater contaminants in U.S. streams, 1999-2000: a national reconnaissance, Environ. Sci. Technol. 36 (2002) 1202-1211.

[2] L. Yang, C. Hu, Y.L. Nie, J.H. Qu, Catalytic ozonation of selected pharmaceuticals over mesoporous alumina-supported manganese oxide, Environ. Sci. Technol. 43 (2009) 2525-2529.

[3] F. Pomati, S. Castiglioni, E. Zuccato, R. Fanelli, D. Vigetti, C. Rossetti, D. Calamari, Effects of a complex mixture of therapeutic drugs at environmental levels on human embryonic cells, Environ. Sci. Technol. 40 (2006) 2442-2447.

[4] T.A. Ternes, M. Meisenheimer, D. McDowell, F. Sacher, H.J. Brauch, B. HaistGulde, G. Preuss, U. Wilme, N. Zulei-Seibert, Removal of pharmaceuticals during drinking water treatment, Environ. Sci. Technol. 36 (2002) 3855-3863.

[5] M. Hartmann, S. Kullmann, H. Keller, Wastewater treatment with heterogeneous Fenton-type catalysts based on porous materials, J. Mater. Chem. 20 (2010) 9002-9017.

[6] S. Navalon, M.D. Miguel, R. Martin, M. Alvaro, H. Garcia, Enhancement of the catalytic activity of supported gold nanoparticles for the Fenton reaction by light, J. Am. Chem. Soc. 133 (2011) 2218-2226.

[7] H. Lim, J. Lee, S. Jin, J. Kim, J. Yoon, T. Hyeon, Highly active heterogeneous Fenton catalyst using iron oxide nanoparticles immobilized in alumina coated mesoporous silica, Chem. Commun. (2006) 463-465.

[8] W. Najjar, S. Perathoner, G. Centi, A. Ghorbel, Activity and stability of (Al-Fe) pillared montmorillonite catalysts for wet hydrogen peroxide oxidation of $\mathrm{p}$ coumaric acid, Stud. Surf. Sci. Catal. 170 (2007) 1425-1431.

[9] M.B. Kasiri, H. Aleboyeh, A. Aleboyeh, Degradation of Acid Blue 74 using FeZSM5 zeolite as a heterogeneous photo-Fenton catalyst, Appl. Catal. B: Environ. 84 (2008) 9-15.

[10] F. Magalhães, M.C. Pereira, S.E.C. Botrel, J.D. Fabris, W.A. Macedo, R. Mendonça, R.M. Lago, L.C.A. Oliveira, Cr-containing magnetites $\mathrm{Fe}_{3-x} \mathrm{Cr}_{x} \mathrm{O}_{4}$ : the role of $\mathrm{Cr}^{3+}$ and $\mathrm{Fe}^{2+}$ on the stability and reactivity towards $\mathrm{H}_{2} \mathrm{O}_{2}$ reactions, Appl. Catal. A: Gen. 332 (2007) 115-123.

[11] J.H. Ma, W.J. Song, C.C. Chen, W.H. Ma, J.C. Zhao, Y.L. Tang, Fenton degradation of organic compounds promoted by dyes under visible irradiation, Environ. Sci. Technol. 39 (2005) 5810-5815.

[12] W.J. Song, M.M. Cheng, J.H. Ma, W.H. Ma, C.C. Chen, J.C. Zhao, Decomposition of hydrogen peroxide driven by photochemical cycling of iron species in clay, Environ. Sci. Technol. 40 (2006) 4782-4787.

[13] D.A. Nichela, A.M. Berkovic, M.R. Costante, M.P. Juliarena, F.S.G. Einschlag, Nitrobenzene degradation in Fenton-like systems using $\mathrm{Cu}(\mathrm{II})$ as catalyst. Comparison between $\mathrm{Cu}(\mathrm{II})$ - and $\mathrm{Fe}(\mathrm{III})$-based systems, Chem. Eng. J. 228 (2013) 1148-1157.

[14] F.L.Y. Lam, A.C.K. Yip, X. Hu, Copper/MCM-41 as a highly stable and pHinsensitive heterogeneous photo-Fenton-like catalytic material for the abatement of organic wastewater, Ind. Eng. Chem. Res. 46 (2007) 3328-3333.

[15] M.K. Eberhardt, G. Ramirez, E. Ayala, Does the reaction of $\mathrm{Cu}^{+}$with $\mathrm{H}_{2} \mathrm{O}_{2}$ give OH radicals? A study of aromatic hydroxylation, J. Org. Chem. 54 (1989) 5922 5926.

[16] J.F. Perez-Benito, Reaction pathways in the decomposition of hydrogen peroxide catalyzed by copper(II), J. Inorg. Biochem. 98 (2004) 430-438. 
[17] K.M. Valkaj, A. Katović, S. Zrnčević, Catalytic properties of Cu/13X zeolite based catalyst in catalytic wet peroxide oxidation of phenol, Ind. Eng. Chem. Res. 50 (2011) 4390-4397.

[18] V. Subbaramaiah, V.C. Srivastava, I.D. Mall, Optimization of reaction parameters and kinetic modeling of catalytic wet peroxidation of picoline by Cu/SBA-15, Ind. Eng. Chem. Res. 52 (2013) 9021-9029.

[19] O.P. Taran, S.A. Yashnik, A.B. Ayusheev, A.S. Piskun, R.V. Prihod'ko, Z.R. Ismagilov, V.V. Goncharuk, Cu-containing MFI zeolites as catalysts for wet peroxide oxidation of formic acid as model organic contaminant, Appl. Catal. B: Environ. 140-141 (2013) 506-515.

[20] H. Irving, R.J.P. Williams, The stability of transition-metal complexes, J. Chem. Soc. (1953) 3192-3210.

[21] N. Wang, L.H. Zhu, M. Lei, Y.B. She, M.J. Cao, H.Q. Tang, Ligand-induced drastic enhancement of catalytic activity of nano- $\mathrm{BiFeO}_{3}$ for oxidative degradation of bisphenol A, ACS Catal. 1 (2011) 1193-1202.

[22] C.R. Keenan, D.L. Sedlak, Ligand-enhanced reactive oxidant generation by nanoparticulate zero-valent iron and oxygen, Environ. Sci. Technol. 42 (2008) 6936-6941.

[23] M. Xia, M.C. Long, Y.D. Yang C. Chen, W.M. Cai, B.X. Zhou, A highly active bimetallic oxides catalyst supported on Al-containing MCM-41 for Fenton oxidation of phenol solution, Appl. Catal. B: Environ. 110 (2011) 118-125.

[24] Y.H. Ling, M.C. Long, P.D. Hu, Y. Chen, J.W. Huang, Magnetically separable coreshell structural $\gamma-\mathrm{Fe}_{2} \mathrm{O}_{3} @ \mathrm{Cu} / \mathrm{Al}-\mathrm{MCM}-41$ nanocomposite and its performance in heterogeneous Fenton catalysis, J. Hazard. Mater. 264 (2014) 195-202.

[25] R. Rosal, A. Rodríguez, J.A. Perdigón-Melón, M. Mezcua, A. Agüera, M.D. Hernando, P. Letón, E. García-Calvo, A.R. Fernández-Alba, Removal of pharmaceuticals and kinetics of mineralization by $\mathrm{O}_{3} / \mathrm{H}_{2} \mathrm{O}_{2}$ in a biotreated municipal wastewater, Water Res. 42 (2008) 3719-3728.

[26] J.S. Bing, C. Hu, Y.L. Nie, M. Yang, J.H. Qu, Mechanism of catalytic ozonation in $\mathrm{Fe}_{2} \mathrm{O}_{3} / \mathrm{Al}_{2} \mathrm{O}_{3} @ S B A-15$ aqueous suspension for destruction of ibuprofen, Environ. Sci. Technol. 49 (2015) 1690-1697.

[27] L.M. Pastrana-Martínez, J.L. Faria, J.M. Doña-Rodríguez, C. FernándezRodríguez, A.M.T. Silva, Degradation of diphenhydramine pharmaceutical in aqueous solutions by using two highly active $\mathrm{TiO}_{2}$ photocatalysts: operating parameters and photocatalytic mechanism, Appl. Catal. B: Environ. 113-114 (2012) 221-227.

[28] F. Yuan, C. Hu, X.X. Hu, J.H. Qu, M. Yang, Degradation of selected pharmaceuticals in aqueous solution with UV and $\mathrm{UV} / \mathrm{H}_{2} \mathrm{O}_{2}$, Water Res. 43 (2009) 1766-1774.

[29] H. Bader, V. Sturzenegger, J. Hoigne, Photometric method for the determination of low concentrations of hydrogen peroxide by the peroxidase catalyzed oxidation of $\mathrm{N}, \mathrm{N}$-diethyl-p-phenylenediamine (DPD), Water Res. 22 (1988) 1109-1115.

[30] Y. Wang, Q. Zhang, T. Shishido, K. Takehira, Characterizations of ironcontaining MCM-41 and its catalytic properties in epoxidation of styrene with hydrogen peroxide, J. Catal. 209 (2002) 186-196.

[31] M.C.N.A. de Carvalho, F.B. Passos, M. Schmal, The behavior of Cu/ZSM-5 in the oxide and reduced form in the presence of NO and methanol, Appl. Catal. A: Gen. 193 (2000) 265-276.

[32] A.C. Pradhan, B. Nanda, K.M. Parida, M. Das, Quick photo-Fenton degradation of phenolic compounds by $\mathrm{Cu} / \mathrm{Al}_{2} \mathrm{O}_{3}-\mathrm{MCM}-41$ under visible light irradiation: small particle size, stabilization of copper, easy reducibility of $\mathrm{Cu}$ and visible light active material, Dalton Trans. 42 (2013) 558-566.
[33] H. Praliaud, S. Mikhailenko, Z. Chajar, M. Primet, Surface and bulk properties of $\mathrm{Cu}-\mathrm{ZSM}-5$ and $\mathrm{Cu} / \mathrm{Al}_{2} \mathrm{O}_{3}$ solids during redox treatments. Correlation with the selective reduction of nitric oxide by hydrocarbons, Appl. Catal. B: Environ. 16 (1998) 359-374.

34] H. Tang Y. Ren, B. Yue, S. Yan, H. He, Cu-incorporated mesoporous materials: synthesis, characterization and catalytic activity in phenol hydroxylation, J. Mol. Catal. A: Chem. 260 (2006) 121-127.

[35] G. Zhang, J. Long, X. Wang, Z. Zhang, W. Dai, P. Liu, Z. Li, L. Wu, X. Fu, Catalytic role of Cu sites of Cu/MCM-41 in phenol hydroxylation, Langmuir 26 (2010) $1362-1371$.

[36] M.R. Prasad, G. Kamalakar, S.J. Kulkarni, K.V. Raghavan, Synthesis of binaphthols over mesoporous molecular sieves, J. Mol. Catal. A: Chem. 180 (2002) 109-123.

[37] F.E. López-Suárez, S. Parres-Esclapez, A. Bueno-López, M.J. Illán-Gómez, B. Ura, J. Trawczynski, Role of surface and lattice copper species in copper-containing $(\mathrm{Mg} / \mathrm{Sr}) \mathrm{TiO}_{3}$ perovskite catalysts for soot combustion, Appl. Catal. B: Environ 93 (2009) 82-89.

[38] B.E. Goodby, J.E. Pemberton, XPS characterization of a commercial $\mathrm{Cu} / \mathrm{ZnO}$ $\mathrm{Al}_{2} \mathrm{O}_{3}$ catalyst: effects of oxidation, reduction, and the steam reformation of methanol, Appl. Spectrosc. 42 (1988) 754-760.

[39] H. Zhang, C. Tang, Y. Lv, C. Sun, F. Gao, L. Dong, Y. Chen, Synthesis characterization, and catalytic performance of copper-containing SBA-15 in the phenol hydroxylation, J. Colloid Interface Sci. 380 (2012) 16-24.

[40] W. Cao, O.K. Tan, J.S. Pan, W. Zhu, C.V.G. Reddy, XPS characterization of $x \alpha-$ $\mathrm{Fe}_{2} \mathrm{O}_{3}-(1-x) \mathrm{ZrO}_{2}$ for oxygen gas sensing application, Mater. Chem. Phys. 75 (2002) 67-70.

[41] W. Luo, L.H. Zhu, N. Wang, H.Q. Tang, M.J. Cao, Y.B. She, Efficient removal of organic pollutants with magnetic nanoscaled $\mathrm{BiFeO}_{3}$ as a reusable heterogeneous Fenton-like catalyst, Environ. Sci. Technol. 44 (2010) 17861791.

[42] Y.N. Lee, R.M. Lago, J.L.G. Fierro, J. Gonzalez, Hydrogen peroxide decomposition over $\mathrm{Ln}_{1-x} \mathrm{~A}_{x} \mathrm{MnO}_{3}$ ( $\mathrm{Ln}=\mathrm{La}$ or $\mathrm{Nd}$ and $\mathrm{A}=\mathrm{K}$ or $\mathrm{Sr}$ ) perovskites, Appl. Catal. A Gen. 215 (2001) 245-256.

[43] Y.L. Nie, C. Hu, J.H. Qu, X. Zhao, Photoassisted degradation of endocrine disruptors over $\mathrm{CuO}_{x}-\mathrm{FeOOH}$ with $\mathrm{H}_{2} \mathrm{O}_{2}$ at neutral pH, Appl. Catal. B: Environ. 87 (2009) 30-36.

[44] H. Tamura, K. Mita, A. Tanaka, M. Ito, Mechanism of hydroxylation of metal oxide surfaces, J. Colloid Interface Sci. 243 (2001) 202-207.

[45] Ž. Mitić, G.S. Nikolić, M. Cakić, P. Premović, L. Ilić, FTIR spectroscopic characterization of $\mathrm{Cu}(\mathrm{II})$ coordination compounds with exopolysaccharide pullulan and its derivatives, J. Mol. Struct. 924-926 (2009) 264-273.

[46] A. Lagutschenkov, R.K. Sinha, P. Maitre, O. Dopfer, Structure and infrared spectrum of the $\mathrm{Ag}^{+}$-phenol ionic complex, J. Phys. Chem. A 114 (2010) 11053-11059.

[47] U.P. Agarwal, R.S. Reiner, Near-IR surface-enhanced Raman spectrum of lignin, J. Raman Spectrosc. 40 (2009) 1527-1534.

[48] S. Bordiga, A. Damin, F. Bonino, G. Ricchiardi, C. Lamberti, A. Zecchina, The structure of the peroxo species in the TS-1 catalyst as investigated by resonant Raman spectroscopy, Angew. Chem. Int. Ed. 41 (2002) 4734-4737.

[49] I.R. Guimaraes, A. Giroto, L.C.A. Oliveira, M.C. Guerreiro, D.Q. Lima, J.D. Fabris, Synthesis and thermal treatment of $\mathrm{Cu}$-doped goethite: oxidation of quinoline through heterogeneous fenton process, Appl. Catal. B: Environ. 91 (2009) 581 586. 